\title{
Tutors' Academic Rationalism Orientation on Instructional Approaches in Primary Teachers' Training Colleges in Kenya
}

\author{
Jacinta Katumbe Mutisya*, Wilfrida Arnodah Itolondo, Samson Ikinya Kariuki \\ Department of Education Management, Policy and Curriculum Studies, Kenyatta University, Kenya
}

Received November 21, 2020; Revised January 1, 2021; Accepted February 3, 2021

\section{Cite This Paper in the following Citation Styles}

(a): [1] Jacinta Katumbe Mutisya, Wilfrida Arnodah Itolondo, Samson Ikinya Kariuki , "Tutors' Academic Rationalism Orientation on Instructional Approaches in Primary Teachers' Training Colleges in Kenya," Universal Journal of Educational Research, Vol. 9, No. 2, pp. 310 - 318, 2021. DOI: 10.13189/ujer.2021.090207.

(b): Jacinta Katumbe Mutisya, Wilfrida Arnodah Itolondo, Samson Ikinya Kariuki (2021). Tutors' Academic Rationalism Orientation on Instructional Approaches in Primary Teachers' Training Colleges in Kenya. Universal Journal of Educational Research, 9(2), 310 - 318. DOI: 10.13189/ujer.2021.090207.

Copyright $\mathrm{C} 2021$ by authors, all rights reserved. Authors agree that this article remains permanently open access under the terms of the Creative Commons Attribution License 4.0 International License

\begin{abstract}
Tutors are the most powerful and influential contributors to the achievement of teacher education curriculum objectives. Tutor beliefs about a knowledge-based curriculum upon which academic rationalism is premised is paramount in intellectual development of teacher trainees. This study sought to determine tutors' preference on the choice of instructional approaches; to determine tutors' level of academic rationalism orientation; and to determine the relationship between tutors' academic rationalism orientation and choice of instructional approaches. This study adopted a correlational design with a mixed methods approach. Tutors' questionnaire, HODs' interview guide, classroom observation and document analysis were used to collect data. Sample population involved 178 tutors, 35 HODs, 20 classrooms and 4 documents purposively sampled from five primary teacher training colleges in Kenya. Descriptive statistics and inferential statistics were used to analyze the study variables as per the study objectives. The study found that there was a significant relationship between tutors' academic rationalism orientation and the choice of instructional approaches they used. However, despite tutors' beliefs on knowledge-based curriculum, there was found to exist methodological gaps as tutors experienced challenges in supervising teacher trainees during teaching practice and in comprehensive coverage of the syllabus involving the practical component. The study concluded that there is need to improve teacher
\end{abstract}

management and professional development so as to improve the quality of education in primary teacher training colleges in Kenya. The study recommended review of deployment of tutors by Teachers Service Commission (TSC) to primary teachers training colleges to capture tutors who have undergone training in teacher education methodology. The study also recommended regular in-service training for tutors to update their skills on the current trends on use of learner centered instructional approaches.

Keywords Academic Rationalism Orientation, Instructional Approaches, Subject Specialization, Subject Scope, Reflective Practices, Assessment Methods

\section{Introduction}

Academic rationalism is concerned with the "what of education'. It is knowledge based so mastery of content is the key concern for academic rationalists. Tutors with an academic rationalism orientation exhibit subject specific pedagogy and assessment skills and have a detailed understanding of the content knowledge of the subject they teach. According to [4],[13],[14],[35], academic rationalism focuses on teaching of the basic fields of study and academic disciplines that are considered more 
important and worth of teaching to unfold learners' interests, cognitive abilities and their intellectual capacity. Tanriverdi and Tezcan [2] assert that subject specialists should focus on selecting content that is most worth teaching, display in depth mastery of subject matter and demonstrate a high degree of intellectual understanding on the knowledge of the subjects they teach in order to produce specialists in their disciplines. Further, [2],[7] argue that teachers' implementation of a curriculum will highly depend on how valuable or worth of teaching they perceive the curriculum. Academic rationalism orientation of tutors is critical in the implementation of teacher education curriculum and in addressing the proposed competency-based curriculum reforms in primary teacher training colleges. Academic rationalism has the implication on how tutors equip the trainees with the $21^{\text {st }}$ Century knowledge through various content areas and the instructional approaches they use [17].

The key indicators of academic rationalism are subject specialization, scope of subject, reflective practices in curriculum implementation and methods of assessments used to test knowledge acquisition. Miller and Seller [25] argued that the beliefs and convictions tutors hold about a knowledge-based curriculum denotes their focus on its relevance and how they perceive teacher trainee mastery of the subject matter. The European Union advocates for subject specialization and teaching of core concepts and skills that take into cognizance the $21^{\text {st }}$ century demands in enhancing lifelong learning [24]. Subject specialization is a good practice since it provides a deeper understanding of subject matter, improves teacher competencies in their disciplines, contributes to effectiveness in teaching as teachers are more comfortable with the subject matter and allows teachers more time to prepare for their lessons [21] Similarly, effective and efficient teaching will depend on the tutors' comprehensive knowledge of the subject matter as well as sense of professionalism achieved through subject specialization [32]. A study conducted in Nigeria on the impact of teachers' subject mastery and questioning behavior on students' performance showed a high correlation between what tutors know and what they teach [33].

Academic rationalists advocate for a narrow but strict subject content scope with an emphasis on the knowledge perspective on what is the best content to enhance a deep understanding and mastery of content [35].The National Academy of Education Committee on teacher education in America advocated for a minimum level of broad scope of interdisciplinary skills and competencies to provide opportunities for diverse, exciting and stimulating lessons that are devoid of similar, meaningless experiences, but create in depth understanding and subject mastery in the particular subject areas [10]. A narrow scope of content that limits students in mastery of content has an implication on the quality of teacher education being offered as opposed to a scope that offers deeper meaning and application of content [16]. The breadth and depth of the subject content play a significant role in providing meanings and deeper insights of the curriculum offered.

Integrating and sharing experiences, emotions, actions and responses with teacher trainees helps enhancing their existing knowledge and understanding concepts. These classroom reflective practices also allow tutors to analyze, discuss, evaluate and change their own practice, as well as adopt an analytical approach towards their beliefs about good teaching [15],[38]. Where tutors have embraced reflective practices in their classrooms such as in Austria, USA, Sweden, Finland, New Zealand and Malaysia, improved communication between tutors and the teacher trainees have been observed as well as improved teaching efficiency and understanding [23],[27]. Similarly, [28],[30] observed that tutors who adequately prepared, reflected and evaluated their lessons and were committed and competent in their teaching contributed to improved students' academic performance. This implies that tutor's reflective practices improve knowledge acquisition as a result of teaching efficiency and effectiveness. Lack of tutor's routine engagement in reflective practices affects their understanding of the effects of their prejudices, beliefs and aspirations, upon which they create, manage, receive, sift and evaluate knowledge [12].

Assessment methods are a significant driving force for achievement of curriculum objectives. Through effective use of assessments, tutors are able to integrate information and experiences, thereby generating a deeper understanding and acquisition of knowledge. A study by [36] found that the interrelationship between concepts in subject matter and the application of knowledge and skills acquired was reflected in the type of assessment method used to evaluate the concepts. In his study on the assessment methods used by tutors in Ethiopia, [1] found that over reliance on use of written assessment methods limited students' creativity and mastery of content in their subject areas. Therefore, the dimension used in organizing for assessment provides an opportunity for knowledge construction and meaning making and contributes to the quality of teaching and learning.

Owing to the increasing emphasis on the quality of education offered in primary teacher training colleges in Kenya, the current push for teacher education reforms is in line with the $21^{\text {st }}$ century skills, professional content knowledge and modern pedagogical skills, it is significant to understand tutors' beliefs with regard to the curriculum they implement, with attention to their orientation on a knowledge-based curriculum. Tutors are vital in successful achievement of teacher education curriculum objectives whose emphasis is on intellectual and professional development of a teacher in terms of content and pedagogical knowledge and skills. An understanding of tutors' academic rationalism orientation could inform the prevailing low academic standards in Kenyan primary teacher training colleges and alleviate the challenges 
affecting quality of teacher education. However, few studies have attempted to investigate tutors' orientation to the teaching of content mastery for most worth knowledge acquisition in relation to how it informs the instructional approaches they use. This study filled this gap by investigating the implications of tutors' academic rationalism orientation on the choice of instructional approaches in selected public primary teachers training colleges in Kenya.

\section{Methodology}

The study was conducted in Aberdare, Kamwenja, Kilimambogo, Murang'a and Thogoto public primary teacher's training colleges between May 2019 and March 2020. The study's main purpose was to investigate the implications of tutors' academic rationalism orientation on the choice of instructional approaches used in public primary teachers training colleges in Kenya. The study was guided by three objectives which were to: determine tutors' preference on the choice of instructional approaches; determine tutors' level of academic rationalism orientation; and determine the relationship between tutors' academic rationalism orientation and choice of instructional approaches. This study used a correlational research design that employed a convergent parallel mixed methods approach. According to [8] correlational research design is appropriate when the researcher wants to describe and measure the degree of association between two or more variables without manipulating any of the variables. The study utilized convergent parallel mixed methods approach to collect quantitative and qualitative data concurrently for purposes of corroborating and validating findings. Quantitative data were collected using questionnaire while qualitative data were collected using interview, observation and document analysis. The entire population of 199 tutors and 35 HODs in the five primary teachers training colleges were purposively sampled as participants to the study since this group of respondents were homogeneous and the number was also manageable. A pilot study was conducted in order to establish the consistency of the internal data, ensure clarity of the questions and instructions and determine any flaws and weakness within the research instruments [3]. Content validity was established by computing Content Validity Index (CVI) based on five experts' judgement and content validity index of 0.88 was achieved and was found relevant for the study [39]. The validity of qualitative data was determined through data triangulation, repeated observation and longevity of observation [34]. Cronbach Coefficient Alpha [9] was used to estimate reliability of the questionnaire and hence enabled the researcher to modify, restructure and remove any items which were ambiguous. The instrument was accepted as reliable at an alpha level of 0.755 . Constant data comparison was used to check on the reliability of data collected qualitatively [34]. Quantitative data were analyzed using descriptive statistics (frequency, mean and standard deviations) and inferential statistics (chi-square test). Qualitative data were analyzed using thematic analysis.

\section{Results}

A questionnaire was distributed to 199 tutors and 178 of them completed and returned constituting a return rate of $89.4 \%$. Kothari [20], rated a return rate of $70 \%$ and above as good therefore the return rate for this study was good. All the 35 Heads of Departments (HODs) were interviewed. A further demographic analysis of participants showed that above half $(56 \%, 60 \%)$ of tutors and HODs are males while female tutors and HODs are fewer $(44 \%, 40 \%)$. Majority $(60 \%)$ of the tutors had a bachelor's degree while majority $(66 \%)$ of HODs had master's degree. The least number of tutors and HODs had diploma and $\mathrm{PhD}$ degree. A vast majority (86\%) of the tutors and HODs (91\%) were aged 41 and above years. Majority (56\%) of the tutors and HODs (77\%) had more than 10 years of teaching experience. Twenty classroom observations were made and 4 documents including primary teacher education syllabus, tutors' professional preparation documents, educational circulars and internal assessment records were analyzed.

\section{Tutors' Choice of Instructional Approaches}

The study found that tutors in primary teachers training colleges used a variety of instructional approaches in their teaching. The study revealed that majority $(62 \%)$ of the tutors used a hybrid of instructional approaches which is a combination of both teacher-centered and learner-centered instructional approaches, some (37\%) of the tutors used teacher centered instructional approaches while $1 \%$ of the tutors used learner-centered approach. Classroom observations conducted confirmed that more tutors (98\%) were aligned to the use of teacher centered instructional approaches where lecture and note taking were most preferred instructional approaches. Comparatively classroom observations showed that fewer tutors $(1 \%)$ engaged in interactive teaching with the teacher trainees through using projects, demonstration and experimentation which were learner centered. An interview conducted with the HODs' revealed that most of the subjects had broad scope of content within which to cover in the two-year teacher training course. This was seen as one reason as to why teacher-centered instructional approaches were most preferred. One of the participants in the Science department noted:

"I am allocated three lessons per week each of one hour. I have seventeen topics to cover in a year each with several sub units. I also do not teach continuously because students break for teaching 
practice each term for three weeks. The only way I can cover the syllabus is by dictating what I want the students to understand. If I allow so many activities in between, I will not cover the content am supposed to cover."

This finding was supported by other participants who confirmed that they had a lot of theory work to cover and limited time given to cover the work could not allow them to engage the student teachers with a lot of activities since by so doing they will be spending time that they felt could be utilized to cover the syllabus. A further analysis showed that tutors' choice of instructional approaches was influenced by the nature of subject they taught, level of subject knowledge, lesson objectives, content to be covered, resources available, assessment methods, personal values, prevailing changes in the society and criticism from teacher trainees. The study showed that three quarter $(75 \%)$ of the tutors' choice of instructional approaches was informed by the nature and level of subject knowledge, more than half $(69 \%)$ of the tutors said that their choice of instructional approaches was influenced by content, objectives and resources available, about $(50 \%)$ of the tutors cited assessments methods to inform their choice of instructional approaches while slightly below half $(45 \%)$ of the tutors said their choice of instructional approaches was influenced by their personal values as well as existing changes in the society. The least number of tutors $(28 \%)$ cited teacher trainee criticism to be an influencing factor with regard to the choice of instructional approaches they used. Figure 1 show tutors' response on the choice of instructional approaches.

\section{Instructional Approaches}

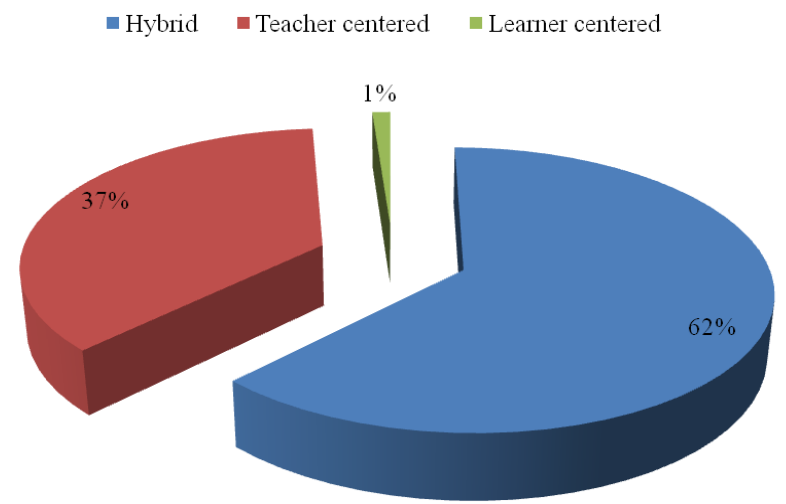

Figure 1. Tutors' Choice of Instructional Approaches

\section{Tutors' Academic Rationalism Orientation}

Tutors' level of academic rationalism orientation was sought. The data were collected using a five-point Likert scale with 8 items. Where $1=$ Strongly Disagree, $2=$ Disagree $3=$ Not sure, 4= Agree and 5=Strongly Agree. For the interpretation of the mean, a score of 1 to 3.4 implied a low preference level of academic rationalism while a score of between 3.5 and 5 meant a high preference of academic rationalism based on the items. Generally, the items sought to find out tutors' academic rationalism orientation based on subject specialization, subject scope, classroom reflective practices and assessment methods used by tutors to test knowledge acquisition of teacher trainees. The results show that tutors were at ease with subjects they were teaching as majority $(88 \%, M=4.085, \mathrm{SD}=1.280)$ of them stated that they taught subjects they had previously been trained on at their undergraduate level. Majority of the tutors $(92 \%, \mathrm{M}=4.429, \mathrm{SD}=1.283)$ taught content described in the teacher education curriculum. However, the preference of tutors as to whether the subjects they taught were most relevant and most worth teaching to teacher trainees was low $(42 \%, \mathrm{M}=3.335 ; \mathrm{SD}=1.222)$. This low preference could be attributed to the tutors' feeling that the primary teacher education curriculum had not been reviewed for a long time and hence limited them to teaching theoretical concepts as opposed to the current trends that require practical approach to teaching and learning. The tutors agreed that subject specialization was relevant in challenging and sharpening knowledge acquisition $(67 \%$, $\mathrm{M}=3.650, \mathrm{SD}=1.214)$. The tutors also supported that subject specialization enhanced content mastery (89\%, $\mathrm{M}=4.119, \mathrm{SD}=1.257$ ). Interviews conducted with HODs revealed that subject specialization provided tutors adequate time to read, internalize and prepare for their lessons. One of the interviewees observed:

"It enhances content mastery. We take time to read and understand topics we are going to teach. We teach only one subject, so one has all the time to read the notes. We are then able to improve our effectiveness in teaching."

However, tutors cited that despite the relevancy of subject specialization they faced challenges in offering supervisory roles to teacher trainees during teaching practice of subjects they had not been trained on. This was because they had not been inducted on primary teaching methods upon being deployed to primary teachers training colleges as most of them had previously been trained to handle secondary school curriculum. One of the HODs interviewed noted that:

"Our most challenging experience as tutors specialized to teach different subjects is when we are sent to the field to supervise a student during the teaching practice; In case one is assigned a student from a different department, which happens so many times, they will have problem advising that student on the best methodology to approach that topic they will present; It happens especially if you have not had interest in that subject they are presenting; yet it is your duty to supervise and advise them to better their teaching skills"

A few tutors $(19 \%, M=2.445, \mathrm{SD}=0.922)$ cited they 
were able to comprehensively cover the primary teacher education curriculum within the stipulated period of two years. An interview with the HODs revealed that the primary teacher education subject scope was wide forcing tutors to teach most of the concepts theoretically so as to cover the syllabus in time. Further findings from the interviews revealed that teacher trainees were minimally exposed to teaching practice exercises. The HODs felt that this limitation denied teacher trainees adequate time to master and practice what they had acquired in class, hence compromising the quality of teacher education. Inadequate exposure to teaching practice could imply poor acquisition of pedagogical content knowledge despite the wide coverage of theoretical lessons. Interview conducted with HODs revealed that most of them felt knowledge acquisition by teacher trainees could be enhanced if they were exposed to more practical activities more so, the teaching practice experience. One of the HODs noted :

"These students should be exposed more to teaching practice in order to improve their competences as teachers. However, the curriculum is so much focused on theory and allows only nine weeks for teaching practice which is distributed to three sessions of three weeks each. One cannot say three weeks is adequate to develop professional competence."

A further analysis showed that $91 \% \quad(\mathrm{M}=4.225$, $\mathrm{SD}=1.274$ ) of the tutors used assessment methods meant to test teacher trainees mastery of content knowledge. Tutors' preparation documents and assessment files showed that most of the evaluation $(91 \%)$ at the college level was based on testing teacher trainees' theoretical understanding of concepts. However, the theoretical evaluation criteria used were superficial as they failed to address aspects of trainees' demonstration on the understanding of tested concepts. Similarly, HODs who were interviewed in relation to assessment methods they used to evaluate knowledge acquisition suggested that they used written tests as they were the means of preparing the teacher trainees to sit their final primary teacher education examination which was also administered in written form. One of the interviewees replied:

"The examination system focuses more on theory as compared to teaching practice. I give more written exercises to my students based on what had been tested in previous years. This ensures they are well prepared to tackle PTE examination at the end of the course"

Results further showed that only $2 \%$ of the tutors constantly reflected on their classroom practices as a means of improving teacher trainees' knowledge acquisition. Classroom observation also showed that tutors shallowly engage in classroom reflective practices. Findings showed that tutors mainly focused on covering the syllabus and initiating the teacher trainees into answering examination questions which limited the interactive nature and critical feedback of reflective practices. Tutors also used questioning techniques as a means of covering the syllabus as opposed to criticizing the teacher trainees' knowledge of the subject matter. It was further observed that teacher trainees were given limited opportunities to critique tutor's teaching with an aim of improving on their teaching competences. The findings on tutors' academic rationalism orientation are presented in Table 1.

Table 1. Tutors' Academic Rationalism Orientation

\begin{tabular}{|l|l|c|c|c|}
\hline No. & \multicolumn{1}{|c|}{ Academic rationalism } & Mean score (M) & Standard deviation (SD) & Interpretation \\
\hline 1. & $\begin{array}{l}\text { I teach subject areas related to my initial professional } \\
\text { training }\end{array}$ & 4.085 & 1.280 & High \\
\hline 2. & Content I teach is drawn strictly from the syllabus & 4.429 & 1.283 & High \\
\hline 3. & $\begin{array}{l}\text { Subject I teach is relevant and more worth teaching to } \\
\text { teacher trainees }\end{array}$ & 3.335 & 1.222 & Low \\
\hline 4. & $\begin{array}{l}\text { Subject specialization is designed to challenge and } \\
\text { sharpen teacher trainee } \\
\text { Knowledge acquisition }\end{array}$ & 3.650 & High \\
\hline 5. & $\begin{array}{l}\text { Subject specialization enhances content mastery } \\
\text { I strictly cover the core content area of my subject within } \\
\text { the stipulated time in the syllabus }\end{array}$ & 4.119 & 1.257 & High \\
\hline 6. & $\begin{array}{l}\text { I constantly reflect on my teaching practices as a means } \\
\text { of improving teacher trainees' knowledge acquisition }\end{array}$ & 3.412 & 0.922 & Low \\
\hline 7. & 4.225 & 1.189 & Low \\
\hline 8. & $\begin{array}{l}\text { Assessment methods I use emphasize on determining } \\
\text { mastery of content by teacher trainees }\end{array}$ & High \\
\hline
\end{tabular}




\section{Relationship between Tutors' Academic Rationalism and Choice of Instructional Approaches}

Chi-square was conducted to establish the relationship between tutors' academic rationalism orientation and choice of instructional approaches. Results showed that there was a significant relationship $\left(\chi^{2}=122.495, \mathrm{df}=56\right.$, $\mathrm{p}=0.000$ ) between academic rationalism and tutors' choice of instructional approaches. The results are presented in Table 2

Table 2. Chi-Square Test for Academic Rationalism and Choice of Instructional Approaches

\begin{tabular}{|c|c|c|c|}
\hline & Value & df & $\begin{array}{c}\text { Asymp. Sig. } \\
(2 \text {-sided })\end{array}$ \\
\hline $\begin{array}{c}\text { Pearson } \\
\text { Chi-Square }\end{array}$ & $122.495^{\mathrm{a}}$ & 56 & .000 \\
\hline Likelihood Ratio & 98.916 & 56 & .000 \\
\hline $\begin{array}{c}\text { Linear-by-Linear } \\
\text { Association }\end{array}$ & 21.160 & 1 & .000 \\
\hline N of Valid Cases & 178 & & \\
\hline
\end{tabular}

\section{Discussion}

Effective use of instructional approaches determines quality of teaching and students' academic performance. The study found that despite tutors' use of hybrid instructional approaches, they were more aligned to the use of teacher-centered instructional approaches as opposed to the more preferred learner centered instructional approaches. This implied that there were methodological gaps which are likely to impact negatively in the development of a holistic teacher as necessitated by the teacher education curriculum objectives in Kenya [18]. The use of learner centered instructional approaches has been known to equip students with adequate competencies [31]. Instructional approaches used by tutors also have a significant role in ensuring that students acquire and master appropriate content knowledge. Buseri and Dorgu [5] stress that where tutors fail to use appropriate instructional approaches, a good curriculum design could turn out to be damaged.

Academic rationalism orientation has a key role to play in enhancing the quality of teacher education as it is premised on the production of experts in the most worth fields of study. This belief ensures that tutors with the best expertise in the various subject areas are deployed in educational institutions so that they can pass on the same knowledge to their students. Tutors are expected to be well equipped with professional content knowledge so that they can transmit the same to the teacher trainees whose knowledge, skills, values and attitudes they acquire have a greater impact on the larger society. In their study [7] found that teacher's beliefs had an impact on their teaching practices and they taught effectively what they felt was worth to be taught This study revealed that tutors perceived subject specialization as important and majority of the tutors taught subjects they were trained to teach during their undergraduate studies. However, these tutors were not adequately prepared to teach teachers' training colleges since they had trained as secondary school or primary school teachers. The findings of the study revealed that tutors deployed to colleges were not given any induction or in-service training upon being released to implement the teacher education curriculum. This had an implication on their teaching methodology as the study found that they experienced challenges in guiding teacher trainees as they supervised them during the teaching practice. Similarly, the tutors' low preference on the fact that subjects they taught were most relevant and worth teaching to teacher trainees has an implication on their teaching efficiency. These aspects are likely to impact on the quality of education offered in primary teacher training colleges in Kenya. According to [11], expert knowledge is largely attained through formal, high quality teacher education during which content knowledge, pedagogical knowledge content and pedagogical knowledge is acquired. Subject specialization gives teachers a sense of professionalism by increasing their efficiency and effectiveness [32]. Subject specialists spend years of learning, deepening their knowledge in their field of study and they will use their specialized content knowledge to empower students' understanding of the subject content and hence improve on quality standards. These points to the need to consistently provide in service training to tutors so that they can be well grounded with subject matter.

The findings of this study also showed that the primary teacher education curriculum was broad and the period of time allocated to teach the content was limited. This resulted into use of theoretical teaching and knowledge-based assessment methods which were not sufficient to evaluate teacher trainees' holistic development. The study further found that tutors' use of reflective practices was low implying insufficient evaluation of their own teaching processes. This is likely to affect tutors' effectiveness in developing teacher trainees' professional, content and pedagogical knowledge. Tutors' competence, commitment and adequate preparation for lessons was found to improve academic performance [28],[30]. According to [29], tutors are key determinants of success in meeting the goals of a system and therefore their competence, resourcefulness and commitment should be considered. Academic rationalism requires that tutors plan activities to use in classroom situation so as to optimize on in depth understanding and knowledge acquisition. The findings of this study therefore have an implication tutors may not be able to evaluate whether teacher trainees have acquired in depth understanding of the content being delivered since their perceived preference of classroom reflective practices was low. This may also imply tutors not being aware of the suitability of the choice of the instructional approaches 
they use. Inadequate reflective practices could have negative impact on the development of teacher trainees' professional competences and hence achievement of the teacher education curriculum objectives. Through reflective practices, the tutor is able to measure the extent of knowledge acquisition of the teacher trainee as they engage in critiquing the lesson and therefore improve on their teaching methodologies as well. The more tutors employ reflective practices in their classroom teaching, the more aware they become of the most suitable instructional approach to use [6]. A study by [37] found a positive relationship between reflective practices and student achievement. According to [38], reflective practices offer teachers an opportunity to renew their classroom practices so that they can understand the influence it has on the instructional approaches and thus, inform them on sound and meaningful teaching and learning practices. The rare use of practical based assessments confirmed by tutors' preference to knowledge-based assessments could be attributed to the fact that the current primary teacher education curriculum [19] provides less guidance on the use of practical based assessments. This trend should be reviewed because use of practical based assessments is one means through which mastery of content can be enhanced as it involves use of instructional approaches that engage the teacher trainees in observing and being able to critique their observation. The findings show that tutors have a strong belief on the use of knowledge-based assessments. This has an implication on the choice of instructional approaches as tutors are likely to use those instructional approaches that engage teacher trainees less, preferably the teacher-centered instructional approaches. The findings of this study agree with [2] that teacher beliefs about curriculum designs affect quality implementation in that if the teacher believes a particular curriculum design is valuable, they will implement it effectively. The findings also agree with [7] who concluded that teacher's beliefs had an impact on their teaching practices and they taught effectively what they felt was worth to be taught. If teachers believe in a curriculum, they will implement it, if they do not believe in it, they will be reluctant to implement and they may even modify it or interfere with it to fit their own ideas [7]. The transmission meta orientation tenet of the theory of curriculum meta orientation [25] posits that tutors should be oriented towards mastery of the most worth knowledge in their subjects and use teacher centered instructional approaches since they are the experts in their subjects to enable the students become specialists in those subjects.

Finally, the study established that tutors' academic rationalism has statistical significance influence on the choice of instructional approaches used in primary teachers' training colleges in selected counties in Kenya. Chi-square tests showed that tutors' academic rationalism significantly influenced their choice of instructional approaches. This finding supports the transmission meta orientation tenet of the theory of curriculum meta orientation [25] that posits that tutors should be oriented towards mastery of the most worth knowledge in their subjects and use instructional approaches that proof their expertise in their subject areas.

\section{Conclusions and Recommendations}

Inputs such as teacher education, professional development and teacher management have been shown to affect quality of education [26]. Despite the Kenyan government's effort to improve teacher education sector through mitigating tutor burn out and skill development by constant deployment of more tutors, establishment of more teacher training colleges as well as initiating professional development programs for tutors such as training in ICT, teachers training colleges have been observed to be performing poorly in academics over a period of time. Therefore, more attention should be paid to ensure that these resources (human, physical and financial) are well utilized to help achieve teacher education curriculum objectives by improving quality of education offered in primary teacher training colleges in Kenya. This study has demonstrated that proper management of tutors is vital in addressing the challenges they are facing, thereby, improving on quality teacher education curriculum delivery.

Tutors cited methodological gaps they experience in guiding teacher trainees during teaching practice despite the fact that they had specialized in their teaching subjects. There is therefore need to upgrade tutors so as to improve their knowledge and skills in the teaching methodology. The study recommends that Teachers' Service Commission (TSC) deploys tutors who have undergone training in teacher education methodology. This can be done alongside offering in -service training to those already teaching in colleges so that they can bridge the gap and understand the implication of their teaching on attainment of teacher education objectives. Vetting of tutors through an interview process will also be helpful in ensuring that only those tutors who understand the primary teacher education methodology are deployed. This is achievable if the policies guiding deployment of tutors to primary teacher training colleges are reviewed.

Owing to the importance attached to subject scope, classroom reflective practices and assessment methods in attaining quality education, the teacher education curriculum objectives and learning experiences need to be improved to focus more on providing tutors with opportunities for interactive engagement with the teacher trainees so as to make teaching and learning learner centered. As Kenya Institute for Curriculum Development (KICD) focus on reviewing the primary teacher education curriculum, they should design a curriculum that can help 
change the mindsets of the tutors on the use of hands-on learning experiences. The learning experiences should also include assessments techniques that are more aligned to practical skills and value acquisition as opposed to the current practice where more emphasis is on theory. This can be achieved by designing a curriculum whose conceptual framework provides clear guidelines on the integration of theory into practice.

The finding of this study shows that tutors' academic rationalism orientation has implication on choice of instructional approaches. Consequently, this has an impact on development of a teaching workforce that are experts in various fields of study. In the changing trends of educational reforms, it is necessary to play close attention to professional development of tutors as these are key determinants of the success of curriculum implementation. Tutors' professional content knowledge has an impact on all spheres of life including teacher education in modern society that expects people to not only be knowledgeable but also apply knowledge of concepts learnt in prevailing social-economic changes.

\section{REFERENCES}

[1] Abatihun, A.S, "A Study on the Assessment Methods and Experiences of Teachers at an Ethiopian University." International Journal of Instruction, Vol.12, no.2, pp.605-622, 2019. https://doi.org/10.29333/iji.2019.12238a.

[2] Apak, O., Tanriverdi, J, "Pre-service teachers beliefs about curriculum orientation," Procedia Social and Behavioral Sciences,Vol.116,no.2,pp.842-845,2014.DOI:10.1016/j.sbs pro.2014.01.308.

[3] Arain, M., Campbell, M. J., Cooper, C. L., Lancaster, G. A, "what is a pilot or Feasibility Study? A review of Current practice and editorial policy," BMC Med Res Methodol., Vol.10, no.67, pp. 1471-2288, 2010. https://doi.org/10.1186 /1471-2288/10/ 67.

[4] Brendan, M, “Understanding curriculum,' Asian Journal of Humanities and Social Studies, Vol.4, no.4, pp.2321-2799, 2016.

[5] Buseri, J. C., Dorgu, T, E, "The relevance of instructional materials for effective curriculum delivery in Nigeria," Journal of Issues in Professional Teacher Education, Vol.2, no.2, pp.9-15, 2011.

[6] Causarano, A, "Preparing Literacy Teachers in an Age of Multiple Literacies: A Self-Reflective Approach,' An International Online Journal, Vol.15,no.2, pp.196-209,2015. DOI:10.13140/RG.2.1.3588.1444.

[7] Cheung, D., Ng, P. H, “'Science Teachers' Beliefs about Curriculum Design,', Research in Education Vol.30, no.4, pp.357-375, 2012. DOI: 10.1007/BF02461556.

[8] Creswell, J. W, “Educational research: planning, conducting and evaluating quantitative and qualitative research,'” (4th ed.) Boston, MA: Pearson Education, 2012.

[9] Cronbach, L. J, "Coefficient alpha and the internal structure of test," Psychometrica, Vol.16, no.3, pp. 297-334, 1951.

[10] Darling-Hammond, L., Newton, X.A., Wei, R. C, "Evaluating Teacher Education Outcomes: A Study of the Stanford Teacher Education Programme," Journal of Education for Teaching: International Research and Pedagogy, Vol.36, no.4, pp.369-388, 2010. DOI:10.1080/0 2607476. 2010.513844.

[11] Darling - Hammond, L, "Teacher Education Around the World: What Can We Learn from International Practice?" European Journal of Teacher Education, Vol.40, no.3, pp.291-309, 2017. DOI:10.1080/02619768.2017.1315399.

[12] Delvin, M., Kift, S., Nelson, K., Smith, E., McKay, J, "Effective Teaching and Support of Students from Low Economic Status Backgrounds: Practical Advice for Teaching Staff. Resources for Australian Higher Education. Australian Government office for Learning and Teaching," Department of Industry, Innovation, Science, Research and Tertiary Education, Sydney, Australia, 2012. http://www.lo wsws.edu.au/assets/ALTC\%20LSES\%20Final\%20Report\% 2012.pdf

[13] Eisner, E, "Five Basic Orientations to the Curriculum in the Educational Imagination; On the Design and Evaluation of School Programs. Macmillan, New York, 1985, pp.61-86.

[14] Ekanem, S.A., Ekefre, E.N, "Philosophical foundation of curriculum development in Nigeria; the essencist model," Journal of Educational and Social Research, Vol.4, no.2, pp.265-271, 2014. DOI: 10.5901/jesr.2014.v4n3p265.

[15] Gimenez, C., Sierra, V., Rodon, J, “'Sustainable Operations: Their Impact on the Tripple Bottom Line,' International Journal of Production Economics, Vol.140, no.1, pp.149-159, 2012. DOI: 10.1016/j.ijpe.2012.01.035.

[16] Kafu, P.A, “Teacher Education in Kenya: Emerging Issues,' International Journal of Curriculum and instruction, Vol.1, no.1, pp.43-53, 2011.

[17] Kenya Institute of Curriculum Development, Teacher Education Curriculum Framework-Masada Draft, 2019. Retrieved from https://kicd.ac.ke.pdf.

[18] Kenya Institute of Curriculum Development, Research Report and Draft Framework for Teacher Education in Kenya, 2016. Retrieved from https://kicd.ac.ke.pdf.

[19] Kenya Institute of Education, Primary Teacher Education Syllabus, Kenya Literature Bureau, Nairobi, 2004.

[20] Kothari, C, "Research Methodology: Methods and Techniques,' New Age International Publishers: New Delhi, 2011.

[21] Kunter, M., Klusmann, U., Baumert, J., Richter, D., Voss, T., Hatchfeld, A, "Professional Competence of Teachers. Effects on Instructional Quality and Student Development," Journal of Educational Psychology, Vol.105, no.3, pp.805-820, 2013, DOI: 10.1037/a0032583.

[22] Laos, M.C, “A Flexible Approach to the EGP Syllabus. Why is it Possible?' Language and Language Teaching Journal, Vol.17, no.1, pp.27-34,2014.DOI:10.24071/IIt.201 


\subsection{4.}

[23] Leon, B, "Teachers Critical Reflective Practice in the Context of the Twenty -First Century Learning," Open Review of Educational Research, Vol.2, no.1, pp.42-54, 2015. http://doi.org/10.1080/23265507.2014.998159.

[24] McMaugh, A., Ardzejewska, K., Coutts, P, “'Delivering the Primary Curriculum: The Use of Subject Specialists and Generalist Teachers in NSW," Issues in Educational Research, Vol.20, no.3, pp.203-219, 2010.

[25] Miller, J. P. \& Seller, W, "Curriculum: Perspectives and Practice,' Longman: Toronto, Canada: Copp Clark Pitman Division, 1990.

[26] Ministry of Education, Science and Technology, National Education Sector Plan, Basic Education Programme Rationale and approach, Vol.1.2013/14-2017/18.Governme nt Printer, Nairobi, 2014.

[27] Minott, M. A, "Reflective Teaching and How it Aids Copying with Heavy Workloads, Mandated Policies and Disagreements with Colleagues," Current Issues in Education, Vol.13, no.1, pp.1-28, 2010.

[28] Moono, M., Mwinsa, G. M., Boyd, M., Sikota, E., Mwiinga, C., Chikanika, W, "The Implementation of Subject Specialization in Primary Schools: An Analysis of its Benefits and Challenges," International Journal of Multidisciplinary Research and Development, Vol.6, no.11, pp.64-72, 2019.

[29] Mtetesha, N, 'Teacher Education and the Student Teacher as an Agent of Change,' 2017.Retrieved from: https://www.academia.edu/4941833/teacher-education-andthe-student-teacher-as-an-agent-of-change

[30] Myrberg, E., Johansson, S., Rosen, M, “The Relation between Teacher Specialization and Student Reading Achievement," Scandivanian Journal of Educational Research, Vol.63, no.5, pp.744-758, 2019.DOI:10.1080/00
313831.2018 .1434826$.

[31] OECD, Education at a glance 2012: Highlights, OECD Publishing,http://dx.doi.org/10.1787/eag-highlights-2012-e $\mathrm{n}$

[32] Ojo, O. O., Akintomide, A. G., Ehindero, S.A, “Primary School Teachers Comfortability with Generalized Teaching in Public Schools in Osun State, Nigeria,' World Journal of Education, Vol.2, no.1, pp.145-153, 2012.

[33] Olowoyeye, C, Abioye, C., Alonge, S, 'Impact of Teachers' Subject Mastery and Questioning Behaviour on Students' Performance in English Language in Selected Senior Secondary Schools in Ikere Metropolis,' Research in Humanities and Social Science, Vol.4, no.14, pp.127-131, 2014.

[34] Punch, K. F, "Introduction to research methods in education. Sage publications ltd, London, 2014.

[35] Schiro, M, “Curriculum Theory: Conflicting Visions and Enduring Concerns," ( $2^{\text {nd }}$ ed) Thousand Oaks, CA: Sage Publications Inc. 2013, pp.1-13.

[36] Sedumedi, T. D, "Practical Work activities as a Method of Assessing Learning in Chemistry Teaching," Eurasia Journal of Mathematics, Science and Technology, Vol.13, no.6, pp.1765-1784, 2017.

[37] Sturkie, L. M, “The Impact of a Reflective Practice Series on the Awareness Level of Six Teacher Candidates at a Public University in the Southeast, 2017, (Doctoral dissertation). Retrieved from https://scholarcommons.sc.ed $\mathrm{u} / \mathrm{etd} / 4306$

[38] Vakalisa, N.C.G., Jacobs, M., Gawe, N, Teaching, Learning Dynamics. Pearson, Cape Town, 2011.

[39] Zhong N.D, "Content validity index in scale development," Pubmed journal, Vol.37 no.2, pp.152-155, 2012. DOI: $10.3969 /$ j.issn.1672-7347.2012.02.007 